\title{
IAMJ
}

INTERNATIONAL

AYURVEDIC

MEDICAL JOURNAL

ISSN: 2320-5091

Impact Factor: 6.719

\section{THE ROLE OF AGNIKARMA IN MUSCULOSKELETAL PAIN MANAGEMENT}

\author{
Shubada V I ${ }^{1}$, Mahabaleshwar $S^{2}$ \\ ${ }^{1}$ Professor, ${ }^{2}$ Associate Professor, Department of ShalyaTantra, \\ Alva's Ayurveda Medical College, Moodbidri, Mangalore -574227, Karnataka, India
}

Corresponding Author:shubada75@gmail.com

https://doi.org/10.46607/iamj2408122020

(Published online: December 2020)

Open Access

(C) International Ayurvedic Medical Journal, India 2020

Article Received: 14/11/2020 - Peer Reviewed: 24/11/2020 - Accepted for Publication: 30/11/2020

Check for updates

\section{ABSTRACT}

Pain is a subjective phenomenon for the assessor but a bothersome and disturbing symptom to many. Many therapies and medicaments to combat pain exist in various medical disciplines. Agnikarma one such promising treatment methodology which manage musculoskeletal pain very effectively. Musculoskeletal pain shares the maximum percentage of pain presentations to outpatient departments. Panchadhatu Shalaka and Madhu (Honey) are the most common and accessible instruments used for Agnikarma. Clinicians witnessed positive results for managing pain in disorders like Low back ache, Sciatica etc. Cost effectiveness, OPD basis treatment and instantaneous pain relief are the optimistic outcomes of Agnikarma therapy.

Keywords: Agnikarma, Musculoskeletal pain, Panchadhatu Shalaka, Madhu

\section{INTRODUCTION}

Vedana (Pain) a synonym for Vyadhi disease) refer often to an entire disease. Symptoms like Katishoola, Shoola in ears, Parshwashoola, Shirashoola etc. are named as independent diseases merely based on the intensity of pain presentation. Many patients worry about the pain rather than pathology of the disease.
Pain is an unpleasant and troublesome sensation to humans. Musculoskeletal pain in particular cripples the person's day to day activities. Agnikarma a promising Parasurgical procedure in Shalya tantra practice has a very positive and instantaneous answer for mus- 
culoskeletal pain. Agnikarma has multifocal avenues based on its vivid indications and mode of action.

\section{Superiority of Agnikarma:}

Agnikarma is the better treatment procedure among parasugical procedures with respect to its actions ${ }^{1}$ (karma) and chosen when all the measures fail to manage a particular ailment. Apunarbhava (No recurrence) action of Agnikarma places it among supreme treatment modalities. Agnikarma therapy is understood as Apunarbhava if followed as per the classical (Poorva, Pradhana and Paschat karmas) methodologies and disease chosen for the treatment is in its Sadhya avastha (curable stage). ${ }^{2}$

Rationale behind selection of instruments for $\boldsymbol{A g}$ nikarma: Agnikarma has been broadly classified into two groups Twakdagda and Mamsadagda .Twakdagda is indicated for Twachasthita and Mamsasthita vyadhis and Mamsadagda is for Sira, Snayu, Asthi and Sandhisthita Vyadhis. ${ }^{3}$ The instruments for Agnikarma are enlisted in classics and instruments are chosen in particular as per stage (acute/chronic) and extent of the disease (superficial or deep tissue involvements). Agnikarma is also classified based on Akara vishesha (shapes)such as Bindu (dot), Lekha line), Valaya and Pratisarana. The method of Agnikarma selection depends upon the underlining disease for Eg: In Rujapradhana vyadhis pain can be pin pointed thus Bindu variety is chosen while In Supthata(numbness) Condition Pratisarana type of Agnikarma in indicated as the numbness is diffuse. Panchadhatushalaka is a commonly used instrument for Agnikarma whereas Madhu, Ghrita etc. Snehadravyas are chosen for deep seated pathologies ${ }^{4}$.

\section{Pathophysiology of Musculoskeletal Pain:}

Musculoskeletal pains are usually the results of Injury, repetitive strains, overuse and also due to adopted poor postures. The Pain affects bones, joints, muscles, tendons, ligaments and even involves nerves. Musculoskeletal pain depends upon the cause of pain and varies from person to person. It may be acute, chronic, diffuse or localized. Pathology ranging from localized inflammation, fibrosis, and tissue degradation leads to hypersensitivity.
Pain, tenderness, weakness, stiffness and functional disturbances are the usual features of various musculoskeletal pains. These features progressively increase with greater tissue injury and inflammation resulting in chronicity of the condition. Low back pain is the most common musculoskeletal pain. Various joint pains, (Knee joint pain being the commonest) muscle cramps/spasm, ligament pains/tears are also quite common. $^{5}$

\section{Management of musculoskeletal pain:}

Treatments which are selected for pain management in musculoskeletal disorders are plenty. Topical applications, injectables, steroid administrations NSAID's and so on. But still there are lots of limitations and recurrences do exist. Ayurveda offers many treatment modalities for effective management of pain. In Ayurveda classics many disorders can be understood under musculoskeletal pain. Katishoola (back ache), Katigraha, (Stiffness) Ghradhrasi, (sciatica) Vishwachi, Greeva hundanam (cervical spondylosis), Sandhigata Vata ((Osteoarthritis), Vatakantaka (Calcaneal spur) etc. share Vata affliction as a common entity in Samprapti. Pain and difficulty in their respective function is the usual presentation of these diseases. Clinical features of these diseases are found very congruent to musculoskeletal pains. Ayurveda offers Shodhana, Shamana and various Sthanika treatment options. Patrapinda sweda, Abhyanga with Nadi sweada, Dhara, Basti etc. offer encouraging results. Agnikarma is also one among the treatment option which can effectively manage musculoskeletal pain. Bindu type of Agnikarma is applied in the management of musculoskeletal pain. Agnikarma can be practiced in any Ritu except Greeshma and Sharat. Pichilaanna sevana is given prior to Agnikarma. Madhu and Ghrita application is done as Paschat Karma ${ }^{6}$. Madhu and Ghrita is the exclusive combination mentioned in various contexts after Agnikarma and Shastra karma. Madhu and Ghrita possess Vrana Shodhana and Ropana properties. Honey has cleansing action on wounds, stimulates tissue regeneration and reduces inflammation. ${ }^{7}$ Ghee is effective in painful ulcers, wounds, insect bites and burn wounds. ${ }^{8}$ 


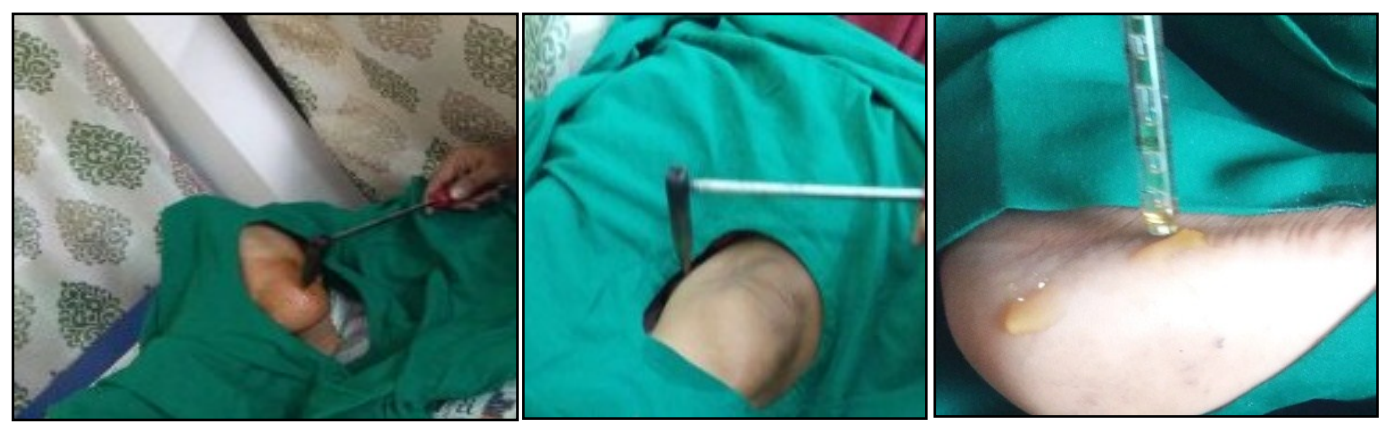

Photographs: Showing Agnikarma in Vatakantaka and Sandhigata vata.

\section{DISCUSSION}

Agnikarma is one of the effective measures for pain management of musculoskeletal pain. Panchadhatu Shalaka and Madhu are commonly used instruments. Instrument used for Agnikarma and the Akara visheshas are selected based on dominant Dosha and Avastha of the disease. Agnikarma acts in Vataja and Kapha afflicted conditions as this therapy has Ushna, Teekshna, Sukshma and Aashukari gunas, which are opposite to Vata and Kaphadosha. By its properties Agnikarma removes Srotorodha and increase the Dhatwagni there by relieving the symptoms. Therapeutic Heat of Agnikarma increases the blood circulation locally and flushes away the Pain producing $\mathrm{P}$ substance. Tapta Madhu has encouraging results in the pain management of cervical spondylosis, Sciatica and low back pain while Panchadhatu shalaka is found more effective in the pain management of joint disorders and plantar fasciitis. Along with Vatahara management protocols Agnikarma will emerge as best treatment option for musculoskeltal pain management. As described in classics Vaidyas should be cautious always during Agnikarma, Kshara karma and Shastra karma.

Acknowledgement: We sincerely acknowledge Advance Research Department, Rajiv Gandhi University of Health Sciences, Bangalore, Karnataka for funding the research project titled "To Study the Therapeutic Efficacy of Agnikarma by Panchadhatu Shalaka and Madhu in Vatakantaka W.S.R to Calcaneal Spur"

\section{CONCLUSION}

Agnikarma is an effective and long-lasting answer for many painful musculoskeletal conditions. Pain man- agement through Agnikarma therapy has encouraging results. Agnikarma by virtue of its properties is effective both in Vata and Kapha afflicted Ruja pradhana vyadhis. Instantaneous and sustainability of pain relief are the positive aspects of the therapy. Panchadhatu shalaka and Madhu emerge as the most common practical and easily accessible tools for Agnikarma.

\section{REFERENCES}

1. Acharya Vaghbhata, AstangaSangraha with shashileka commentary by Indu edited by Dr Shivprasad Sharma $5^{\text {th }}$ edition 2018 Chaukamba surabharati Prakashan Varanasi Sutrasthana 40/2 page no-263.

2. Acharya Sushrutha, Sushrutha samhita with Nibandha sangraha commentary of dalhanacharya and Nyaya Chandrika Panchika of Gayadasa on nidanasthana edited by Vaidya Jadavaji Trikamji Acharya Reprint Edition 2014: Chaukamba surabharati Prakashan Varanasi, Sutrasthana, Agnikarma vidhi adhyaya 12/3 page no-51.

3. Acharya Sushrutha, Sushrutha samhita with Nibandha sangraha commentary of Dalhanacharya and Nyaya Chandrika Panchika of Gayadasa on nidanasthana edited by Vaidya Jadavaji Trikamji Acharya Reprint Edition 2014: Chaukamba surabharati Prakashan Varanasi, Sutrasthana, Agnikarma vidhi adhyaya 12/4 page no-51.

4. Acharya Vaghbhata, Astanga Sangraha with shashileka commentary by Indu edited by Dr Shivprasad Sharma $5^{\text {th }}$ edition 2018: Chaukamba surabharati Prakashan Varanasi, Sutrasthana 40/5 page no-263.

5. https://www.healthline.com/health/tgct/musculoskeleta 1-pain\#types

6. Vaghbhata, Astanga Hridaya with Sarvangasundara commentary of Arunadatta and Ayrveda Rasayana commentary of Hemadri edited by Dr Anna Moreshwar 
Kunte Revised edition, 2018: Chaukamba surabharati Prakashan Varanasi, Sutrasthana 30/44 page no-359.

7. Tahereh Eteraf-Oskouei ${ }^{1,2}$ andMoslem Najafi June 2013 Traditional and Modern Uses of Natural Honey in Human Diseases: A Review16(6): 731-742

8. https://foreverconscious.com/the-healing-properties-ofghee

\section{Source of Support: Nil}

\section{Conflict of Interest: None Declared}

How to cite this URL: Shubada V I \& Mahabaleshwar S: The Role of Agnikarma In Musculoskeletal Pain Management. International Ayurvedic Medical Journal \{online\} 2020 \{cited December, 2020\} Available from: http://www.iamj.in/posts/images/upload/5351_5354.pdf 